\title{
Osteoarthritis and the Mediterranean Diet: A Systematic Review
}

\author{
Isabel Morales-Ivorra ${ }^{1, *(1)}$, Montserrat Romera-Baures ${ }^{1}$, Blanca Roman-Viñas ${ }^{2,3,4}$ \\ and Lluis Serra-Majem 4,5,6 iD \\ 1 Department of Rheumatology, Bellvitge University Hospital-IDIBELL, L'Hospitalet de Llobregat, \\ 08907 Barcelona, Spain; m.romera@bellvitgehospital.cat \\ 2 School of Health and Sport Sciences (EUSES), University of Girona, 17190 Salt, Spain; dietmed@fin.pcb.ub.es \\ 3 Blanquerna Faculty of Psychology, Education Sciences and Sport (FPCEE), Universitat Ramon Llull, \\ 08022 Barcelona, Spain \\ 4 CIBER Fisiopatología de la Obesidad y Nutrición (CIBERobn), Instituto de Salud Carlos III (ISCIII), \\ 28029 Madrid, Spain; lluis.serra@ulpgc.es \\ 5 Research Institute of Biomedical and Health Sciences IUIBS, University of Las Palmas de Gran Canaria, \\ 35001 Las Palmas de Gran Canaria, Spain \\ 6 Nutrition Research Foundation, University of Barcelona Science Park, 08028 Barcelona, Spain \\ * Correspondence: imoralesi@bellvitgehospital.cat; Tel.: +34-663-787-990
}

Received: 3 July 2018; Accepted: 1 August 2018; Published: 7 August 2018

check for Abstract: Osteoarthritis (OA) affects 240 million people globally. Few studies have examined
the links between osteoarthritis and the Mediterranean diet (MD). The aim of this paper was to
systematically review and analyze the epidemiological evidence in humans on the MD and its
association with OA. A systematic search of EMBASE identified three studies that explored the
association between MD and OA. Two of them were cross-sectional and the third one was a 16-week
randomized clinical trial. Prisma declaration was followed to carry out this review. These studies
described a positive association between a higher adherence to a MD and the quality of life of
participants suffering OA. The prevalence of OA was lower in participants with a higher adherence
to a Mediterranean diet. Biomarkers of inflammation and cartilage degradation related to OA were
also analyzed and significant differences were detected only for IL1- $\alpha$, which decreased in the
MD group. Exploring the relationship between MD and OA is complex, moreover, the limited
evidence and methodological differences in such studies makes it difficult to compare results.
In conclusion, the three studies included in this systematic review demonstrated some relation
between osteoarthritis and a Mediterranean diet. However, prospective and longer interventions are
required to evaluate the long-term efficacy of the Mediterranean diet to improve symptomatology
and preventing osteoarthritis.

Keywords: Mediterranean diet; osteoarthritis; systematic review

\section{Introduction}

Dietary patterns in Mediterranean countries during the early 1960s have been linked to increased longevity and reduced morbidity as compared with those in Northern Europe and the USA [1]. More recently, several publications have demonstrated the benefits of a Mediterranean diet (MD) in reducing cardiovascular risks, certain subtypes of cancer, chronic diseases and in improving cognitive health [2-6]. Although definitions of MD vary, all of them include high consumption of fruit, vegetables, legumes, nuts, seeds and cereals; greater intakes of fish and seafood; moderate consumption of dairy products, poultry and eggs; as well as frequent, but moderate, intake of red wine and olive oil as the main source of dietary lipids [7-10]. 
Osteoarthritis (OA) affects 240 million people globally, about $10 \%$ of men and $18 \%$ of women [11]. Clinical manifestations of $\mathrm{OA}$ are pain, transient morning stiffness and crepitus with joint motion, all of which deteriorate daily quality of life, leading to increased morbidity and mortality [12]. The most common risk factors for OA include age, gender, prior joint injury, obesity, genetic predisposition and mechanical factors [13,14]. The link between obesity and OA is multifactorial. Historically, excessive body weight leads to wear and tear of the joint [15]. The association between overweight and hand osteoarthritis suggests that factors other than mechanical forces may play also a role [16]. Nowadays, it is accepted that obesity induces low-grade systemic inflammation caused by the secretion of proinflammatory adipokines and cytokines. These dysregulated secretions are known to contribute to joint degeneration during OA $[17,18]$. Moreover, it has been demonstrated that a high consumption of n-6 fatty acids results in an elevated risk of subchondral bone deterioration and that a high fat diet increases leptin levels in local cartilage tissue contributing to accelerated progression of OA [19,20].

Nowadays, the management of OA focuses on the alleviation of symptoms. International recommendations for the management of OA include three main categories: non-pharmacological, pharmacological and surgical [21]. It is widely accepted that weight loss and physical activity form part of the non-pharmacological treatment strategies for OA [22,23]. Moreover, some studies have demonstrated that nutrition can have a beneficial role in osteoarthritis [24-26]. Different groups have demonstrated a protector effect of the Mediterranean diet in OA because of its anti-inflammatory properties, reversion of the metabolic syndrome (MetS) and obesity and antioxidant capacity [27-29]. MD is rich in polyphenols which prevent inflammation and cartilage destruction, resulting in a prevention of osteoarthritis-related musculoskeletal inflammation [30]. MD also produces a lower $\mathrm{n}-6$ to n-3 fatty acid (FA) ratio. Compounds derived from n-3 FA decrease gene expression of proteinases cartilage lesions and inflammatory cytokines. By contrast, a high intake of n-6 FA is suggested to induce inflammatory processes, resulting in increasing cartilage damage [31]. Some studies have reported that the intake of dietary antioxidants such as vitamin $\mathrm{C}$ prevents the progression of $\mathrm{OA}$ and drops off the prevalence of radiographic knee OA [32,33].

Hence, the aim of the current study was to systematically review and analyze epidemiological studies on the links between MD and osteoarthritis.

\section{Materials and Methods}

An EMBASE search was conducted up to December 2017 in order to identify epidemiological studies on MD and OA. The search strategy applied was as follows: ('osteoarthritis'/exp/mj OR 'osteoarthritis' / major focus term (mj)) AND ('Mediterranean diet'/exp/mj OR 'Mediterranean $\operatorname{diet}^{\prime} / \mathrm{mj}$ ). All human epidemiological studies with full texts were considered. Additional papers were identified during the manual search process. Exclusion criteria were applied to selected studies: studies in languages other than English and studies evaluating nutrients or foods individually. The Prisma guidelines were followed during our review [34].

The quality of the studies included in the review was analyzed using the relevant tool for cross-sectional studies [35]. For the randomized controlled trial, we assessed the risk of bias (low, high or unclear) for the following domains: random sequence generation, allocation concealment, blinding of assessments, incomplete outcome data, and selective Newcastle-Ottawa Scale outcome reporting [36]. The study was classified as having a high risk of bias if any one domain was at high risk of bias and a low risk of bias if four or five domains were classified as at low risk. Otherwise, the risk of bias for the trial was considered to be unclear. 


\section{Results}

The EMBASE search strategy ('osteoarthritis'/exp/mj OR 'osteoarthritis'/mj) AND ('Mediterranean diet'/exp/mj OR 'Mediterranean diet'/mj) yielded a total of eight articles. After applying the selection criteria, three publications were selected. The flowchart showing the procedures for selecting the studies is shown in Figure 1. Table 1 shows the main characteristics of the selected articles and Table S2 shows a summary of their main findings [37-39]. Two articles reported cross-sectional data from the same study, namely the Osteoarthritis Initiative conducted in the USA [38,39], while the third was a randomized controlled trial [37]. The risk of bias was fair in both cross-sectional studies and unclear in the randomized controlled trial.

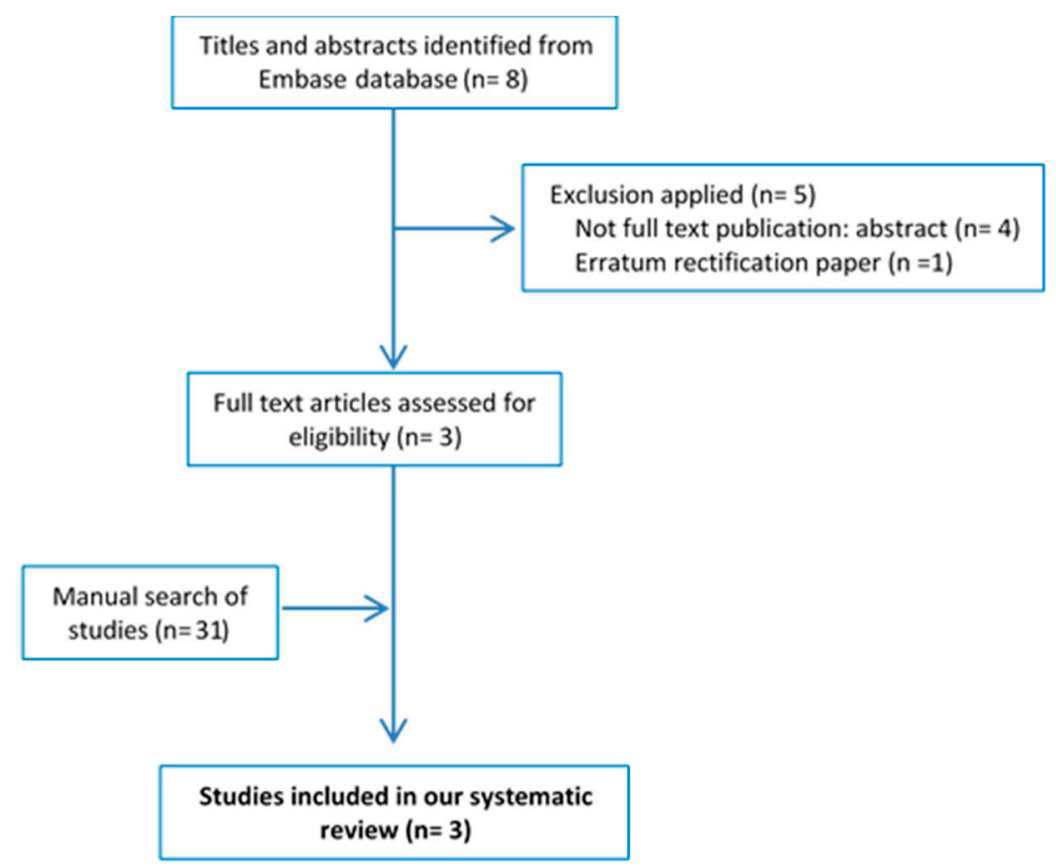

Figure 1. Flowchart for the systematic review. 
Table 1. Epidemiological studies on mediterranean diet and osteoarthritis.

\begin{tabular}{|c|c|c|c|c|c|c|}
\hline Author, Year & $\begin{array}{l}\text { Country } \\
\text { Population, N } \\
\text { (sex) Age }\end{array}$ & $\begin{array}{c}\text { Sample } \\
\text { Characteristics }\end{array}$ & $\begin{array}{l}\text { MD Definition. Diets and } \\
\text { Other Interventions }\end{array}$ & Osteoarthritis & Follow-Up & Results \\
\hline $\begin{array}{l}\text { Dyer J et al., } \\
2017 \text { [37]. }\end{array}$ & $\begin{array}{l}\text { UK } \\
\mathrm{N}=99 \\
(83 \% \text { female }) \\
\text { Age: } \\
\text { 31-90 years. }\end{array}$ & $\begin{array}{l}\text { Volunteers with a } \\
\text { clinician diagnosis } \\
\text { of OA. } \\
\text { 16-week dietary } \\
\text { intervention } \\
(\mathrm{N}=50) \text { and control } \\
(\mathrm{N}=49) \text {. }\end{array}$ & $\begin{array}{l}\text { Fruit, vegetables, legumes, } \\
\text { olive oil, fish and shellfish, } \\
\text { poultry, cereals (refined and } \\
\text { whole grain), red and } \\
\text { processed meat, animal fat, } \\
\text { sugary drinks, sweets } \\
\text { and pastries. } \\
\text { Completed a 7-day food } \\
\text { diary (as a food frequency } \\
\text { questionnaire). }\end{array}$ & $\begin{array}{l}\text { Clinician diagnosis } \\
\text { of OA. }\end{array}$ & $\begin{array}{l}\text { Food frequency questionnaire } \\
\text { and an Arthritis Impact } \\
\text { Measurement Scale (AIMS2) } \\
\text { questionnaire at baseline, } \\
2 \text { months and } 4 \text { months }(\mathrm{end}) \text {. } \\
\text { Subset patients (DIET }=33 \text {, } \\
\text { CON }=28 \text { ) were asked about } \\
\text { joint range of motion (ROM) at } \\
\text { start and end of study and to } \\
\text { provide blood samples } \\
\text { (DIET }=29, \text { CON }=25 \text { ) for } \\
\text { biomarker analysis. }\end{array}$ & $\begin{array}{l}\text { AIMS2 components and most } \\
\text { biomarkers } p>0.05, \text { except IL-1 } 1 \alpha \text { in } \\
\text { the DIET group }(\sim 47 \%, p=0.010) \text {. } \\
\downarrow \text { Markers of cartilage degradation } \\
\text { in the DIET group }(\sim 8 \%, p=0.014) \text {. } \\
\uparrow \text { Knee flexion and hip rotation ROM } \\
\text { in the DIET group }(p<0.05) \text {. }\end{array}$ \\
\hline $\begin{array}{l}\text { Veronese N et al., } \\
2016 \text { [38]. }\end{array}$ & $\begin{array}{l}\text { USA } \\
\mathrm{N}=4358 \\
(2527 \text { females }) \\
\text { Mean age: } \\
61.2 \pm 9.1 \text { years. }\end{array}$ & $\begin{array}{l}\text { Community-dwelling } \\
\text { participants from the } \\
\text { Osteoarthritis } \\
\text { Initiatives were } \\
\text { included }\end{array}$ & $\begin{array}{l}\text { The Mediterranean diet score } \\
\text { proposed by Panagiotakos } \\
\text { et al. was used to evaluate } \\
\text { aMED categorized into } \\
\text { quartiles [40]. }\end{array}$ & $\begin{array}{l}\text { Knee OA was diagnosed } \\
\text { both clinically and } \\
\text { radiologically. } \\
\text { The presence of pain, } \\
\text { stiffness, and physical } \\
\text { functioning due to OA } \\
\text { was assessed through } \\
\text { the WOMAC. } \\
\text { The responses for each } \\
\text { subscale (pain, stiffness, } \\
\text { disability) are categorized } \\
\text { on Likert scale (0-4). }\end{array}$ & $\begin{array}{l}\text { Block Brief } 2000 \text { food frequency } \\
\text { questionnaire (FFQ) during the } \\
\text { baseline visit. }\end{array}$ & $\begin{array}{l}\uparrow \text { aMED } \downarrow \text { prevalence of knee OA } \\
\text { (Q4: } 25.2 \% \text { vs. Q1: } 33.8 \% ; p<0.0001 \text { ) } \\
\text { Highest aMED } \downarrow \text { in presence of knee } \\
\text { OA (OR: } 0.83 ; 95 \% \text { CIs: } 0.69-0.99, \\
p<0.04 \text { ). } \\
\text { Among individual components of } \\
\text { MD only higher use of cereals } \downarrow \\
\text { odds of knee OA (OR: } 0.76 ; 95 \% \text { CI: } \\
0.60 \mathrm{e} 0.98 ; p<0.03 \text { ). }\end{array}$ \\
\hline $\begin{array}{l}\text { Veronese N et al., } \\
2017 \text { [39]. }\end{array}$ & $\begin{array}{l}\text { USA } \\
\mathrm{N}=4470 \\
(2605 \text { females }) \\
\text { Mean age: } \\
61.3 \pm 9.2 \text { years. }\end{array}$ & $\begin{array}{l}\text { Community-dwelling } \\
\text { participants from the } \\
\text { Osteoarthritis. } \\
\text { Initiatives were } \\
\text { included. }\end{array}$ & $\begin{array}{l}\text { The Mediterranean diet score } \\
\text { proposed by Panagiotakos } \\
\text { et al. [40] was used to } \\
\text { evaluate aMED categorized } \\
\text { into quintiles. }\end{array}$ & & $\begin{array}{l}\text { Block Brief } 2000 \text { food frequency } \\
\text { questionnaire (FFQ) during the } \\
\text { baseline visit. } \\
\text { Quality of life as primary } \\
\text { outcome (SF-12) physical } \\
\text { composite scale (PCS) and } \\
\text { Mental composite scale (MCS). } \\
\text { Secondary outcomes: } \\
\text { WOMAC (pain, stiffness, } \\
\text { disability caused by OA). } \\
\text { Depressive symptoms (CES-D } \\
\text { instrument) [41]. }\end{array}$ & $\begin{array}{l}\uparrow \text { aMED } \uparrow \text { SF-12 PCS (Q5 } 50 \pm 8.5 \text { vs } \\
\text { Q1 47.2 } \pm 9.8 p<0.0001) \text { and } \\
\text { SF-12MCS (Q5 } 54.5 \pm 7.6 \text { vs. Q1 } 53.2 \\
\pm 8.8 p<0.0001) . \\
\uparrow \text { aMED } \downarrow \text { WOMAC (except for } \\
\text { stiffness). } \\
\uparrow \text { aMED } \downarrow \text { CES-D }(\beta-0.05 ; 95 \% \text { CI: } \\
-0.09,-0.01 ; p<0.05) .\end{array}$ \\
\hline
\end{tabular}

AIMS2: Arthritis Impact Measurement Scale; aMED: Adherence to the Mediterranean diet; CES-D: Center for Epidemiologic Studies Depression Scale instrument; FFQ: food frequency questionnaire; MCS: Mental composite scale of SF-12; MD: Mediterranean Diet; OA: Osteoarthritis; PCS: Physical composite scale of SF-12; ROM: Range of motion; SF-12: 12-Item Short-Form Health Outcome Survey; WOMAC: Western Ontario and McMaster Universities Arthritis Index. 


\subsection{Characteristics of the Study Sample}

The studies were conducted between 2004-2013 in the UK and North America. The cross-sectional study was evaluated between more than 4000 participants, while the randomized control trial included 124 patients. In each study, a different principal variable of OA was analyzed: biomarkers and range of motion of knee and hip, OA prevalence and quality of life. All studies were published in last two years [37-39].

\subsection{Evaluation of $M D$}

In the Dyer et al. (2017) article, the participants in the diet group were provided with nutritional information and dietary advice regarded as adequately informative for patients from non-Mediterranean countries. All participants were asked to complete a 7-day food diary and a score to evaluate their compliance with the diet was calculated [37].

Veronese et al. (2016) analyzed the dietary patterns using the Block Brief 200 food-frequency questionnaire. Adherence to the Mediterranean diet was calculated using the scoring system proposed by Panangiotakos et al. (aMED) [38-40].

\subsection{Prevalence of $O A$ in Participants with High Adherence to $M D$}

The prevalence of knee OA was significantly lower in participants with higher aMED $(\mathrm{OR}=0.83$; 95\% CI: 0.69-0.99, $p=0.04$ ). When the effects of individual components of MD and their association with the presence of knee OA were analyzed, only a higher consumption of cereals was associated with a significantly reduced probability of knee OA (OR: $0.76 ; 95 \%$ CI: $0.60-0.98 ; p=0.03$ ) [38].

\subsection{Quality of Life and MD Adherence}

Quality of life was investigated as a primary outcome through the 12-Item Short-Form Health Outcome Survey (SF-12), which has a physical (PCS) and mental (MCS) composite scale. The scores range from 0 to 100, with higher scores indicating a better quality of life. Participants with higher aMED had significantly higher SF-12: SF-12-PCS (Q5 $50 \pm 8.5$ vs. Q1 $47.2 \pm 9.8 p<0.0001$ ) and SF-12MCS (Q5 $54.5 \pm 7.6$ vs. Q1 $53.2 \pm 8.8 p<0.0001$ ) [38].

The presence of any depressive symptoms was analyzed using the 20-item Center for Epidemiologic Studies Depression Scale (CES-D) instrument [41]. Higher scores indicate more depressive symptoms. Participants with higher aMED had lower CES-D scores $(\beta-0.05 ; 95 \% \mathrm{CI}$ : $-0.09,-0.01 ; p<0.05)$ [38].

Western Ontario and McMaster Universities Arthritis Index (WOMAC) is a validated scale for assessing the presence of pain, stiffness and disability caused by OA. Participants with higher aMED had a significantly lower WOMAC in both knees for subscales of pain (Right knee $-0.02(-0.04,-0.01)$; $p=0.008) /($ Left knee $-0.02(-0.04,-0.003) ; p=0.02)$ and disability (Right knee $-0.08(-0.14,-0.03)$; $p=0.004) /$ Left Knee $-0.07(-0.14,-0.01) ; p=0.02)$ but not for stiffness $(p>0.05)$ [38].

The Arthritis Impact Measurement Scale (AIMS2) is a disease-specific measure of the physical, social, and emotional well-being designed as a measure of outcome in arthritis. It encompasses nine scales: mobility, physical activity (walking, bending, lifting), dexterity, household activity, social activities, daily living activities, pain, depression, and anxiety. Dyer et al. (2017) compared AIMS2 in the diet and control groups and no significant associations emerged [37].

Dyer et al. (2017) compared the range of motion of the lower extremities in both the diet (MD diet) and control groups. Knee flexion and hip rotation in the diet group were better than those observed in the control group ( $122 \pm 18$ vs. $116 \pm 29 ; p=0.072) 52 \pm 19$ vs. $46 \pm 24 ; p=0.010$ ). No significant differences between groups were observed in terms of index finger movement and hip flexion $(p>0.05)[37]$. 


\subsection{Markers of Inflammation and Cartilage Degradation}

The serum cartilage oligomeric matrix protein (sCOMP) and inflammatory cytokines, chemokines and growth factors have been linked to OA. Dyer et al. (2017) analyzed different biomarkers in participants with OA in both the Diet and Control groups: sCOMP, IL-1 $\beta$, IL- $1 \alpha$, IL-2, IL-4, IL-6, IL-8, IL-10, IFN- $\gamma$, TNF- $\alpha$, VEGF, EGF and soluble receptors (IL-6sR, IL-2sR, TNF-sR1 and TNF-sR2, plus MCP-1, and MMP-9). Significant differences between groups were only detected in IL1- $\alpha$ $(p=0.019)$, which decreased in the diet group, but which showed no change in the control group [37].

\section{Discussion}

The findings of this systematic review indicate positive associations between MD and improved quality of life in participants with OA [37-39]. The prevalence of osteoarthritis was lower in participants with high aMED [38]. Biomarkers of inflammation and cartilage degradation related to OA were also analyzed and significant differences were detected for IL1- $\alpha(p=0.019)$, which was lower in the diet group [37].

There are several physiological explanations that could explain why key components of MD might protect against OA. OA is often referred to as a degenerative joint disease. This is inaccurate since OA is not simply a process of wear and tear. Chronic low-grade inflammation has been described as a key mediator of the pathogenesis of OA [42]. In fact, elevated serum levels of the $\mathrm{C}$-reactive protein, a marker of inflammation, are predictive of the development and progression of OA [43]. Inflammation in OA joints is distinct from that in rheumatoid arthritis as it is chronic, low grade and mediated by innate immunity [42]. Different studies have shown that the presence of synovial inflammation, or synovitis, in OA is associated with increased severity of joint symptoms, increased cartilage loss, decreased mobility, and elevated radiographic grades [44-46]. Most likely, not only local but also systemic inflammation is related to OA development [47]. Obesity induces low-grade systemic inflammation caused by the secretion of proinflammatory adipokines and cytokines, which both contribute to joint degeneration during OA $[17,18]$. The cytokines from the synovial fluid contribute to cartilage matrix loss by stimulating chondrocyte catabolic activity and inhibiting anabolic activity $[48,49]$. Thus, the known association between a higher adherence to a MD and lower level markers of inflammation could explain some of the benefits [50-52]. Some studies have found that consuming MD reduces weight and IL-6 levels. This effect is greater if it is accompanied by exercise $[53,54]$.

Several studies have described an increased risk of OA in association with such metabolic risk factors as dyslipidemia, hypertension, and insulin resistance, which characterize the MetS [20,55-57]. The prevalence of MetS in patients with OA is $59 \%$ and in the general population 23\% [55]. Patients with OA and MetS suffer an increased incidence of inflammation and pain compared to OA patients without MetS $[58,59]$. The treatment of MetS has been proposed as measure to delay the progression of OA [60].

The MD has been shown not only to reverse MetS [61-64], but also to improve quality of life [65,66]. On the other hand, olive oil, which is an important component of MD, has proven to be efficient in reducing pain, WOMAC scores and in improving the Health Assessment Questionnaire-Disability Index in patients with OA [67-70].

This body of evidence suggests that MD may reduce the prevalence of $\mathrm{OA}$ and improve the quality of life in these patients because of its anti-inflammatory effects. The absence of differences between the Diet and Control groups in terms of the biomarkers is probably a consequence of the short period of exposition to MD (only 16 weeks) or to the difficulties in adopting a MD in non-Mediterranean countries [71]. 


\section{Conclusions}

The findings of this systematic review should be weighed against certain limitations. Only three papers met the inclusion criteria. Two of the studies were of cross-sectional design (and evaluated the same population group) while the third was a randomized trial. There are important methodological differences in the studies that make it difficult to compare their results. In conclusion, the three studies included in this systematic review demonstrate some relation between OA and adherence to the MD. However, the epidemiological evidence is limited, and longer interventions are required to evaluate the long-term efficacy of the MD for improving symptomatology and preventing OA.

Supplementary Materials: The following are available online at http://www.mdpi.com/2072-6643/10/8/ 1030/s1, Table S1: PRISMA-P 2015 Checklist, Table S2: Summary of results of epidemiological studies on the Mediterranean diet and Osteoarthritis.

Author Contributions: I.M.-I., M.R.-B. and L.S.-M. contributed equally to researching data for the article, discussions of content, writing the article and review/editing of the manuscript before submission. B.R.-V. made substantial contributions to researching data for the article, discussions of content and review/editing of the manuscript before submission.

Funding: This research received no external funding.

Acknowledgments: We would like to thank Joan Miquel Nolla Sole and Mariela Nissensohn for their support for this work.

Conflicts of Interest: The authors declare no conflict of interest.

\section{Abbreviations}

AIMS2 Arthritis Impact Measurement Scale

aMED Adherence to the Mediterranean diet

CES-D Center for Epidemiologic Studies Depression Scale instrument

FA Fatty acid

FFQ food frequency questionnaire

MCS Mental composite scale of SF-12

MD Mediterranean Diet

MetS metabolic syndrome

OA Osteoarthritis

PCS Physical composite scale of SF-12

ROM Range of motion

sCOMP Serum cartilage oligomeric matrix protein

SF-12 12-Item Short-Form Health Outcome Survey

WOMAC Western Ontario and McMaster Universities Arthritis Index

\section{References}

1. Willett, W.C.; Sacks, F.; Trichopoulou, A.; Drescher, G.; Ferro-Luzzi, A.; Helsing, E.; Trichopoulos, D. Mediterranean diet pyramid: A cultural model for healthy eating. Am. J. Clin. Nutr. 1995, 61, 1402S-1406S. [CrossRef] [PubMed]

2. Dinu, M.; Pagliai, G.; Casini, A.; Sofi, F. Mediterranean diet and multiple health outcomes: An umbrella review of meta-analyses of observational studies and randomised trials. Eur. J. Clin. Nutr. 2018, 72, 30-43. [CrossRef] [PubMed]

3. De Lorgeril, M.; Salen, P. The Mediterranean-style diet for the prevention of cardiovascular diseases. Public Health Nutr. 2006, 9, 118-123. [CrossRef] [PubMed]

4. Miranda, A.; Gómez-Gaete, C.; Mennickent, S. Role of Mediterranean diet on the prevention of Alzheimer disease. Rev. Med. Chile 2017, 145, 501-507. [CrossRef] [PubMed]

5. Schwingshackl, L.; Missbach, B.; König, J.; Hoffmann, G. Adherence to a Mediterranean diet and risk of diabetes: A systematic review and meta-analysis. Public Health Nutr. 2015, 18, 1292-1299. [CrossRef] [PubMed] 
6. Serra-Majem, L.; Roman, B.; Estruch, R. Scientific evidence of interventions using the Mediterranean diet: A systematic review. Nutr. Rev. 2006, 64, S27-S47. [CrossRef] [PubMed]

7. Bach-Faig, A.; Berry, E.M.; Lairon, D.; Reguant, J.; Trichopoulou, A.; Dernini, S.; Medina, F.X.; Battino, M.; Belahsen, R.; Miranda, G.; et al. Mediterranean diet pyramid today. Science and cultural updates. Public Health Nutr. 2011, 14, 2274-2284. [CrossRef] [PubMed]

8. Davis, C.; Bryan, J.; Hodgson, J.; Murphy, K. Definition of the Mediterranean Diet; a Literature Review. Nutrients 2015, 7, 9139-9153. [CrossRef] [PubMed]

9. Serra-Majem, L.; Trichopoulou, A.; Ngo de la Cruz, J.; Cervera, P.; García Alvarez, A.; La Vecchia, C.; Lemtouni, A.; Trichopoulos, D. International Task Force on the Mediterranean Diet Does the definition of the Mediterranean diet need to be updated? Public Health Nutr. 2004, 7, 927-929. [CrossRef] [PubMed]

10. Trichopoulou, A.; Martínez-González, M.A.; Tong, T.Y.; Forouhi, N.G.; Khandelwal, S.; Prabhakaran, D.; Mozaffarian, D.; de Lorgeril, M. Definitions and potential health benefits of the Mediterranean diet: Views from experts around the world. BMC Med. 2014, 12, 112. [CrossRef] [PubMed]

11. Nelson, A.E. Osteoarthritis year in review 2017: Clinical. Osteoarthr. Cartil. 2018, 26, 319-325. [CrossRef] [PubMed]

12. Martel-Pelletier, J.; Barr, A.J.; Cicuttini, F.M.; Conaghan, P.G.; Cooper, C.; Goldring, M.B.; Goldring, S.R.; Jones, G.; Teichtahl, A.J.; Pelletier, J.-P. Osteoarthritis. Nat. Rev. Dis. Primer 2016, 2, 16072. [CrossRef] [PubMed]

13. Felson, D.T.; Lawrence, R.C.; Dieppe, P.A.; Hirsch, R.; Helmick, C.G.; Jordan, J.M.; Kington, R.S.; Lane, N.E.; Nevitt, M.C.; Zhang, Y.; et al. Osteoarthritis: New insights. Part 1: The disease and its risk factors. Ann. Intern. Med. 2000, 133, 635-646. [CrossRef] [PubMed]

14. Johnson, V.L.; Hunter, D.J. The epidemiology of osteoarthritis. Best Pract. Res. Clin. Rheumatol. 2014, 28 , 5-15. [CrossRef] [PubMed]

15. Sowers, M.R.; Karvonen-Gutierrez, C.A. The evolving role of obesity in knee osteoarthritis. Curr. Opin. Rheumatol. 2010, 22, 533-537. [CrossRef] [PubMed]

16. Yusuf, E.; Nelissen, R.G.; Ioan-Facsinay, A.; Stojanovic-Susulic, V.; DeGroot, J.; van Osch, G.; Middeldorp, S.; Huizinga, T.W.J.; Kloppenburg, M. Association between weight or body mass index and hand osteoarthritis: A systematic review. Ann. Rheum. Dis. 2010, 69, 761-765. [CrossRef] [PubMed]

17. Thijssen, E.; van Caam, A.; van der Kraan, P.M. Obesity and osteoarthritis, more than just wear and tear: Pivotal roles for inflamed adipose tissue and dyslipidaemia in obesity-induced osteoarthritis. Rheumatology 2015, 54, 588-600. [CrossRef] [PubMed]

18. Pottie, P.; Presle, N.; Terlain, B.; Netter, P.; Mainard, D.; Berenbaum, F. Obesity and osteoarthritis: More complex than predicted! Ann. Rheum. Dis. 2006, 65, 1403-1405. [CrossRef] [PubMed]

19. Datta, P.; Zhang, Y.; Parousis, A.; Sharma, A.; Rossomacha, E.; Endisha, H.; Wu, B.; Kacprzak, I.; Mahomed, N.N.; Gandhi, R.; et al. High-fat diet-induced acceleration of osteoarthritis is associated with a distinct and sustained plasma metabolite signature. Sci. Rep. 2017, 7, 8205. [CrossRef] [PubMed]

20. Jungmann, P.M.; Kraus, M.S.; Alizai, H.; Nardo, L.; Baum, T.; Nevitt, M.C.; McCulloch, C.E.; Joseph, G.B.; Lynch, J.A.; Link, T.M. Association of metabolic risk factors with cartilage degradation assessed by T2 relaxation time at the knee: Data from the osteoarthritis initiative. Arthritis Care Res. 2013, 65, 1942-1950. [CrossRef] [PubMed]

21. Zhang, W.; Nuki, G.; Moskowitz, R.W.; Abramson, S.; Altman, R.D.; Arden, N.K.; Bierma-Zeinstra, S.; Brandt, K.D.; Croft, P.; Doherty, M.; et al. OARSI recommendations for the management of hip and knee osteoarthritis: Part III: Changes in evidence following systematic cumulative update of research published through January 2009. Osteoarthr. Cartil. 2010, 18, 476-499. [CrossRef] [PubMed]

22. Fernandes, L.; Hagen, K.B.; Bijlsma, J.W.J.; Andreassen, O.; Christensen, P.; Conaghan, P.G.; Doherty, M.; Geenen, R.; Hammond, A.; Kjeken, I.; et al. European League Against Rheumatism (EULAR) EULAR recommendations for the non-pharmacological core management of hip and knee osteoarthritis. Ann. Rheum. Dis. 2013, 72, 1125-1135. [CrossRef] [PubMed]

23. McAlindon, T.E.; Bannuru, R.R.; Sullivan, M.C.; Arden, N.K.; Berenbaum, F.; Bierma-Zeinstra, S.M.; Hawker, G.A.; Henrotin, Y.; Hunter, D.J.; Kawaguchi, H.; et al. OARSI guidelines for the non-surgical management of knee osteoarthritis. Osteoarthr. Cartil. 2014, 22, 363-388. [CrossRef] [PubMed]

24. Ameye, L.G.; Chee, W.S. Osteoarthritis and nutrition. From nutraceuticals to functional foods: A systematic review of the scientific evidence. Arthritis Res. Ther. 2006, 8, R127. [CrossRef] [PubMed] 
25. Lopez, H.L. Nutritional interventions to prevent and treat osteoarthritis. Part I: Focus on fatty acids and macronutrients. PMER 2012, 4, S145-S154. [CrossRef]

26. Thomas, S.; Browne, H.; Mobasheri, A.; Rayman, M.P. What is the evidence for a role for diet and nutrition in osteoarthritis? Rheumatology 2018, 57, iv61-iv74. [CrossRef] [PubMed]

27. Pitaraki, E.E. The role of Mediterranean diet and its components on the progress of osteoarthritis. J. Frailty Sarcopenia Falls 2017, 2, 45-52. [CrossRef]

28. Felson, D.T.; Bischoff-Ferrari, H.A. Dietary fatty acids for the treatment of OA, including fish oil. Ann. Rheum. Dis. 2016, 75, 1-2. [CrossRef] [PubMed]

29. Chin, K.-Y.; Pang, K.-L. Therapeutic Effects of Olive and Its Derivatives on Osteoarthritis: From Bench to Bedside. Nutrients 2017, 9, 1060. [CrossRef] [PubMed]

30. Shen, C.-L.; Smith, B.J.; Lo, D.-F.; Chyu, M.-C.; Dunn, D.M.; Chen, C.-H.; Kwun, I.-S. Dietary polyphenols and mechanisms of osteoarthritis. J. Nutr. Biochem. 2012, 23, 1367-1377. [CrossRef] [PubMed]

31. Knott, L.; Avery, N.C.; Hollander, A.P.; Tarlton, J.F. Regulation of osteoarthritis by omega-3 (n-3) polyunsaturated fatty acids in a naturally occurring model of disease. Osteoarthr. Cartil. 2011, 19, 1150-1157. [CrossRef] [PubMed]

32. Li, H.; Zeng, C.; Wei, J.; Yang, T.; Gao, S.-G.; Li, Y.-S.; Lei, G.-H. Associations between dietary antioxidants intake and radiographic knee osteoarthritis. Clin. Rheumatol. 2016, 35, 1585-1592. [CrossRef] [PubMed]

33. Chiu, P.-R.; Hu, Y.-C.; Huang, T.-C.; Hsieh, B.-S.; Yeh, J.-P.; Cheng, H.-L.; Huang, L.-W.; Chang, K.-L. Vitamin C Protects Chondrocytes against Monosodium Iodoacetate-Induced Osteoarthritis by Multiple Pathways. Int. J. Mol. Sci. 2016, 18, 38. [CrossRef] [PubMed]

34. Liberati, A.; Altman, D.G.; Tetzlaff, J.; Mulrow, C.; Gøtzsche, P.C.; Ioannidis, J.P.A.; Clarke, M.; Devereaux, P.J.; Kleijnen, J.; Moher, D. The PRISMA statement for reporting systematic reviews and meta-analyses of studies that evaluate healthcare interventions: Explanation and elaboration. BMJ 2009, 339, b2700. [CrossRef] [PubMed]

35. Wells, G.A.; Shea, B.; O'Connell, D.; Peterson, J.; Welch, V.; Losos, M. The Newcastle-Ottawa Scale (NOS) for Assessing the Quality of Nonrandomised Studies in Meta-Analyses; The Ottawa Hospital Research Institute: Ottawa, ON, Canada, 2016.

36. Higgins, J.P.T.; Green, S. Cochrane Handbook for Systematic Reviews of Interventions, Version 5.1.0; The Cochrane Collaboration: London, UK, 2011.

37. Dyer, J.; Davison, G.; Marcora, S.M.; Mauger, A.R. Effect of a Mediterranean Type Diet on Inflammatory and Cartilage Degradation Biomarkers in Patients with Osteoarthritis. J. Nutr. Health Aging 2017, 21, 562-566. [CrossRef] [PubMed]

38. Veronese, N.; Stubbs, B.; Noale, M.; Solmi, M.; Luchini, C.; Maggi, S. Adherence to the Mediterranean diet is associated with better quality of life: Data from the Osteoarthritis Initiative. Am. J. Clin. Nutr. 2016, 104, 1403-1409. [CrossRef] [PubMed]

39. Veronese, N.; Stubbs, B.; Noale, M.; Solmi, M.; Luchini, C.; Smith, T.O.; Cooper, C.; Guglielmi, G.; Reginster, J.-Y.; Rizzoli, R.; et al. Adherence to a Mediterranean diet is associated with lower prevalence of osteoarthritis: Data from the osteoarthritis initiative. Clin. Nutr. 2017, 36, 1609-1614. [CrossRef] [PubMed]

40. Panagiotakos, D.B.; Pitsavos, C.; Stefanadis, C. Dietary patterns: A Mediterranean diet score and its relation to clinical and biological markers of cardiovascular disease risk. Nutr. Metab. Cardiovasc. Dis. 2006, 16, 559-568. [CrossRef] [PubMed]

41. Carleton, R.N.; Thibodeau, M.A.; Teale, M.J.; Welch, P.G.; Abrams, M.P.; Robinson, T.; Asmundson, G.J. The Center for Epidemiologic Studies Depression Scale: A Review with a Theoretical and Empirical Examination of Item Content and Factor Structure. PLoS ONE 2013, 8, e58067. [CrossRef] [PubMed]

42. Robinson, W.H.; Lepus, C.M.; Wang, Q.; Raghu, H.; Mao, R.; Lindstrom, T.M.; Sokolove, J. Low-grade inflammation as a key mediator of the pathogenesis of osteoarthritis. Nat. Rev. Rheumatol. 2016, 12, 580-592. [CrossRef] [PubMed]

43. Pelletier, J.P.; Martel-Pelletier, J.; Abramson, S.B. Osteoarthritis, an inflammatory disease: Potential implication for the selection of new therapeutic targets. Arthritis Rheum. 2001, 44, 1237-1247. [CrossRef]

44. Ayral, X.; Pickering, E.H.; Woodworth, T.G.; Mackillop, N.; Dougados, M. Synovitis: A potential predictive factor of structural progression of medial tibiofemoral knee osteoarthritis-Results of a 1 year longitudinal arthroscopic study in 422 patients. Osteoarthr. Cartil. 2005, 13, 361-367. [CrossRef] [PubMed] 
45. Roemer, F.W.; Guermazi, A.; Felson, D.T.; Niu, J.; Nevitt, M.C.; Crema, M.D.; Lynch, J.A.; Lewis, C.E.; Torner, J.; Zhang, Y. Presence of MRI-detected joint effusion and synovitis increases the risk of cartilage loss in knees without osteoarthritis at 30-month follow-up: The MOST study. Ann. Rheum. Dis. 2011, 70, 1804-1809. [CrossRef] [PubMed]

46. Sowers, M.; Karvonen-Gutierrez, C.A.; Jacobson, J.A.; Jiang, Y.; Yosef, M. Associations of anatomical measures from MRI with radiographically defined knee osteoarthritis score, pain, and physical functioning. J. Bone Jt. Surg. Am. 2011, 93, 241-251. [CrossRef] [PubMed]

47. Berenbaum, F. Osteoarthritis as an inflammatory disease (osteoarthritis is not osteoarthrosis!). Osteoarthr. Cartil. 2013, 21, 16-21. [CrossRef] [PubMed]

48. Griffin, T.M.; Guilak, F. The role of mechanical loading in the onset and progression of osteoarthritis. Exerc. Sport Sci. Rev. 2005, 33, 195-200. [CrossRef] [PubMed]

49. Loeser, R.F.; Goldring, S.R.; Scanzello, C.R.; Goldring, M.B. Osteoarthritis: A disease of the joint as an organ. Arthritis Rheum. 2012, 64, 1697-1707. [CrossRef] [PubMed]

50. Ahluwalia, N.; Andreeva, V.A.; Kesse-Guyot, E.; Hercberg, S. Dietary patterns, inflammation and the metabolic syndrome. Diabetes Metab. 2013, 39, 99-110. [CrossRef] [PubMed]

51. Bonaccio, M.; Cerletti, C.; Iacoviello, L.; de Gaetano, G. Mediterranean diet and low-grade subclinical inflammation: The Moli-sani study. Endocr. Metab. Immune Disord. Drug Targets 2015, 15, 18-24. [CrossRef] [PubMed]

52. Estruch, R. Anti-inflammatory effects of the Mediterranean diet: The experience of the PREDIMED study. Proc. Nutr. Soc. 2010, 69, 333-340. [CrossRef] [PubMed]

53. Messier, S.P.; Mihalko, S.L.; Legault, C.; Miller, G.D.; Nicklas, B.J.; DeVita, P.; Beavers, D.P.; Hunter, D.J.; Lyles, M.F.; Eckstein, F.; et al. Effects of intensive diet and exercise on knee joint loads, inflammation, and clinical outcomes among overweight and obese adults with knee osteoarthritis: The IDEA randomized clinical trial. JAMA 2013, 310, 1263-1273. [CrossRef] [PubMed]

54. Esposito, K.; Kastorini, C.-M.; Panagiotakos, D.B.; Giugliano, D. Mediterranean diet and weight loss: Meta-analysis of randomized controlled trials. Metab. Syndr. Relat. Disord. 2011, 9, 1-12. [CrossRef] [PubMed]

55. Puenpatom, R.A.; Victor, T.W. Increased prevalence of metabolic syndrome in individuals with osteoarthritis: An analysis of NHANES III data. Postgrad. Med. 2009, 121, 9-20. [CrossRef] [PubMed]

56. Sowers, M.; Karvonen-Gutierrez, C.A.; Palmieri-Smith, R.; Jacobson, J.A.; Jiang, Y.; Ashton-Miller, J.A. Knee osteoarthritis in obese women with cardiometabolic clustering. Arthritis Rheum. 2009, 61, 1328-1336. [CrossRef] [PubMed]

57. Yoshimura, N.; Muraki, S.; Oka, H.; Kawaguchi, H.; Nakamura, K.; Akune, T. Association of knee osteoarthritis with the accumulation of metabolic risk factors such as overweight, hypertension, dyslipidemia, and impaired glucose tolerance in Japanese men and women: The ROAD study. J. Rheumatol. 2011, 38, 921-930. [CrossRef] [PubMed]

58. Monira Hussain, S.; Wang, Y.; Cicuttini, F.M.; Simpson, J.A.; Giles, G.G.; Graves, S.; Wluka, A.E. Incidence of total knee and hip replacement for osteoarthritis in relation to the metabolic syndrome and its components: A prospective cohort study. Semin. Arthritis Rheum. 2014, 43, 429-436. [CrossRef] [PubMed]

59. Shin, D. Association between metabolic syndrome, radiographic knee osteoarthritis, and intensity of knee pain: Results of a national survey. J. Clin. Endocrinol. Metab. 2014, 99, 3177-3183. [CrossRef] [PubMed]

60. Yudoh, K.; Karasawa, R. Statin prevents chondrocyte aging and degeneration of articular cartilage in osteoarthritis (OA). Aging 2010, 2, 990-998. [CrossRef] [PubMed]

61. Alvarez León, E.E.; Henríquez, P.; Serra-Majem, L. Mediterranean diet and metabolic syndrome: A cross-sectional study in the Canary Islands. Public Health Nutr. 2006, 9, 1089-1098. [CrossRef] [PubMed]

62. Babio, N.; Toledo, E.; Estruch, R.; Ros, E.; Martínez-González, M.A.; Castañer, O.; Bulló, M.; Corella, D.; Arós, F.; Gómez-Gracia, E.; et al. Mediterranean diets and metabolic syndrome status in the PREDIMED randomized trial. Can. Med. Assoc. J. 2014, 186, E649-E657. [CrossRef] [PubMed]

63. Esposito, K.; Kastorini, C.-M.; Panagiotakos, D.B.; Giugliano, D. Mediterranean diet and metabolic syndrome: An updated systematic review. Rev. Endocr. Metab. Disord. 2013, 14, 255-263. [CrossRef] [PubMed]

64. Roman, B.; Carta, L.; Martínez-González, M.A.; Serra-Majem, L. Effectiveness of the Mediterranean diet in the elderly. Clin. Interv. Aging 2008, 3, 97-109. [PubMed] 
65. Henríquez Sánchez, P.; Ruano, C.; de Irala, J.; Ruiz-Canela, M.; Martínez-González, M.A.; Sánchez-Villegas, A. Adherence to the Mediterranean diet and quality of life in the SUN Project. Eur. J. Clin. Nutr. 2012, 66, 360-368. [CrossRef] [PubMed]

66. Ruano, C.; Henriquez, P.; Martínez-González, M.Á.; Bes-Rastrollo, M.; Ruiz-Canela, M.; Sánchez-Villegas, A. Empirically derived dietary patterns and health-related quality of life in the SUN project. PLoS ONE 2013, 8, e61490. [CrossRef] [PubMed]

67. Bitler, C.M.; Matt, K.; Irving, M.; Hook, G.; Yusen, J.; Eagar, F.; Kirschner, K.; Walker, B.; Crea, R. Olive extract supplement decreases pain and improves daily activities in adults with osteoarthritis and decreases plasma homocysteine in those with rheumatoid arthritis. Nutr. Res. 2007, 27, 470-477. [CrossRef]

68. Bohlooli, S.; Jastan, M.; Nakhostin-Roohi, B.; Mohammadi, S.; Baghaei, Z. A pilot double-blinded, randomized, clinical trial of topical virgin olive oil versus piroxicam gel in osteoarthritis of the knee. J. Clin. Rheumatol. Pract. Rep. Rheum. Musculoskelet. Dis. 2012, 18, 99-101. [CrossRef] [PubMed]

69. Gelmini, F.; Ruscica, M.; Macchi, C.; Bianchi, V.; Maffei Facino, R.; Beretta, G.; Magni, P. Unsaponifiable Fraction of Unripe Fruits of Olea europaea: An Interesting Source of Anti-inflammatory Constituents. Planta Med. 2016, 82, 273-278. [CrossRef] [PubMed]

70. Takeda, R.; Koike, T.; Taniguchi, I.; Tanaka, K. Double-blind placebo-controlled trial of hydroxytyrosol of Olea europaea on pain in gonarthrosis. Phytomed. Int. J. Phytother. Phytopharm. 2013, 20, 861-864. [CrossRef] [PubMed]

71. Hoffman, R.; Gerber, M. Evaluating and adapting the Mediterranean diet for non-Mediterranean populations: A critical appraisal. Nutr. Rev. 2013, 71, 573-584. [CrossRef] [PubMed]

(C) 2018 by the authors. Licensee MDPI, Basel, Switzerland. This article is an open access article distributed under the terms and conditions of the Creative Commons Attribution (CC BY) license (http:// creativecommons.org/licenses/by/4.0/). 